\title{
Design and synthesis of intramolecular hydrogen bonding systems. Their application in metal cation sensing based on excited-state proton transfer reaction
}

\author{
Kun-Chan Wu, ${ }^{\mathrm{a}}$ Yu-Shan Lin, ${ }^{\mathrm{a}} \mathrm{Yu}-\mathrm{Shan}$ Yeh, ${ }^{\mathrm{a}}$ Chun-Yen Chen, ${ }^{\mathrm{a}}$ Moawia O. Ahmed, \\ Pi-Tai Chou ${ }^{\mathrm{a}, *}$ and Yung-Son Hon ${ }^{\mathrm{b}, *}$ \\ ${ }^{a}$ Department of Chemistry, National Taiwan University, Taipei 106, Taiwan \\ ${ }^{\mathrm{b}}$ Department of Chemistry and Biochemistry, National Chung Cheng University, Chia-Yi 621, Taiwan
}

Received 14 July 2004; revised 22 September 2004; accepted 24 September 2004

Available online 18 October 2004

\begin{abstract}
We reported the design and synthesis of a new type of metal-cation probes, 3-hydroxy-4-(1,4,7,10-tetraoxa-13azacyclopentadec-13-ylmethyl)naphthalene-2-carbaldehyde (1a) and its single hydrogen-bond analogue 1-(1,4,7,10-tetraoxa-13-azacylopentadec-13-ylmethyl)-2-naphthol (2a), in which 1-aza-15-crown-5 ether in combination with the naphthol oxygen acts as a receptor, while the mechanism of excited-state intramolecular proton transfer (ESIPT) is exploited as a signal transducer. The association constant of $(2.5 \pm 0.5) \times 10^{4},(3.8 \pm 0.4) \times 10^{4},(5.5 \pm 0.5) \times 10^{3}$ and $(1.2 \pm 0.3) \times 10^{4} \mathrm{M}^{-1}$ for the formation of $1 \mathrm{a} / \mathrm{Na}^{+}, \mathbf{1 a} / \mathrm{Ca}^{2+}, \mathbf{2 a} / \mathrm{Na}^{+}$and $\mathbf{2 a} / \mathrm{Ca}^{2+}$ complexes, respectively, in $\mathrm{CH}_{3} \mathrm{CN}$ plus drastic fluorescence changes due to the fine-tuning of ESIPT reaction upon complexation, lead 1a and 2a to be highly sensitive fluorescent sensors. The results add a new class into the category of metal-cation probes, with the perspective of designing ESIPT systems capable of sensing bio-analytes.
\end{abstract}

(C) 2004 Elsevier Ltd. All rights reserved.

\section{Introduction}

Due to its importance in fundamental research, the excited state intramolecular proton transfer (ESIPT) process has received considerable attention. ${ }^{1}$ The ESIPT reaction generally incorporates transfer of a hydroxyl (or amino) proton to the carbonyl oxygen (or pyridinic nitrogen) through a pre-existing six or five membered ring hydrogen bonding (HB) configuration. The resulting proton-transfer tautomer, which generally possesses a vast difference in electronic configuration from its corresponding normal species, exhibits a large Stokes shifted fluorescence. This unusual photophysical property has led to versatile applications such as the development of laser dyes, ${ }^{2,3}$ probes for solvation environments, ${ }^{4,5}$ ultraviolet stabilizers ${ }^{6}$ and radiation hard-scintillator counters, ${ }^{7}$ etc.

Recently, we have applied 1-[(diethylamino)methyl]-3hydroxy-2-naphthaldehyde (DMHN) possessing dual HB

Keywords: Hydrogen bonding; Metal-cation probes; Excited state intramolecular proton transfer reaction; Receptors.

* Corresponding authors. Tel.: +86622363 0231x3988; fax: +8862 23695208 (P.T.C.); e-mail addresses: chop@ntu.edu.tw; cheysh@ccu.edu.tw sites (conformers $\mathbf{A}$ and $\mathbf{B}$, see Scheme 1) to study the competitive ESIPT dynamics. ${ }^{8}$ Despite a near degeneracy in the ground electronic state, conformers $\mathbf{A}$ and $\mathbf{B}$ undergo entirely different ESIPT dynamics, resulting in a zwitterion $\left(\lambda_{\max } \sim 485 \mathrm{~nm}\right)$ and a keto-tautomer $\left(\lambda_{\max } \sim 730 \mathrm{~nm}\right)$ emission, respectively. From the application viewpoint, one intriguing concept is to design ESIPT systems capable of capturing analytes and selectively blocking one HB site. The result may drastically alter the ESIPT pathway, and the associated photophysics can thus be exploited as a new type of sensor for molecule/metal-ion recognition. On this basis, we have designed 3-hydroxy-4-(1,4,7,10-tetraoxa-13-azacyclopentadec-13-ylmethyl)naphthalene-2-carbaldehyde (1a) and its single HB analogue 1-(1,4,7,10-tetraoxa-13azacylopentadec-13-ylmethyl)-2-naphthol (2a). 1a and 2a were synthesized from the condensation between 3-hydroxy-naphthalene-2-carbaldehyde (3HN) (or 2-naphthol for 2a) and 1-aza-15-crown-5 ether via a modified Mannich reaction depicted in Scheme 2, in which $3 \mathrm{HN}$ was prepared from the reduction of 3-hydroxy-2-naphthoic acid methyl ester. Both prove to be highly sensitive fluorescent sensors based on the mechanism incorporating metal cation fine-tuning ESIPT reaction, adding a new class into the category of metal-cation probes. ${ }^{9,10}$ 


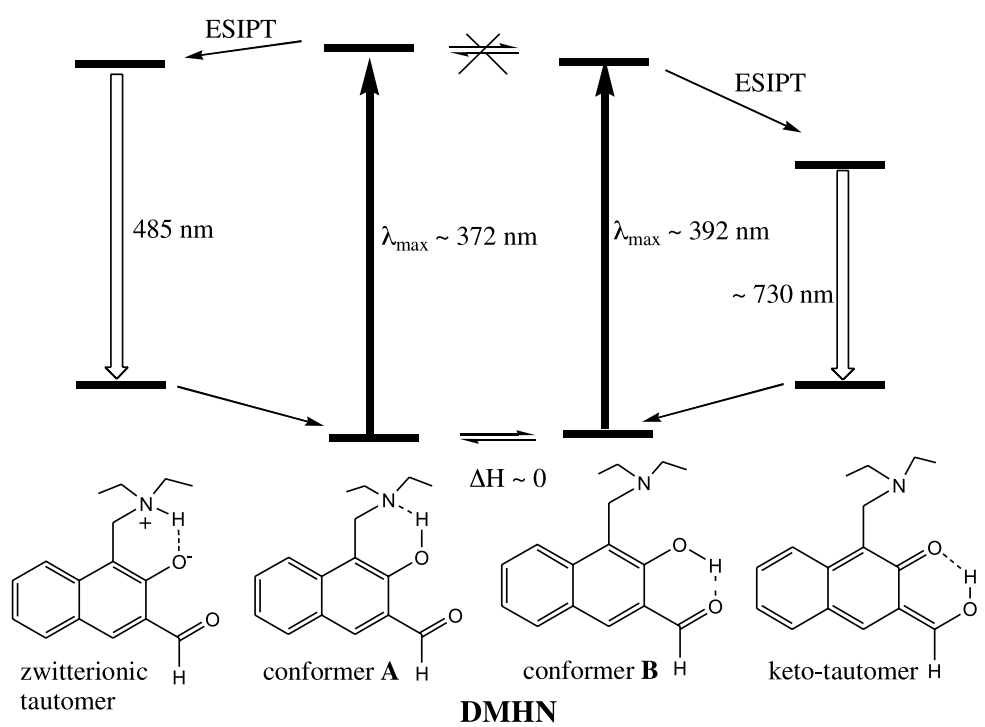

Scheme 1. The proposed competitive ESIPT mechanism for DMHN in aprotic solvents. ${ }^{8}$ It should be noted that the rate of interconversion between conformers $\mathbf{A}$ and $\mathbf{B}$ in the excited state is too slow to compete with the proton transfer process. Thus, each hydrogen-bonding conformer undergoes independent ESIPT process.
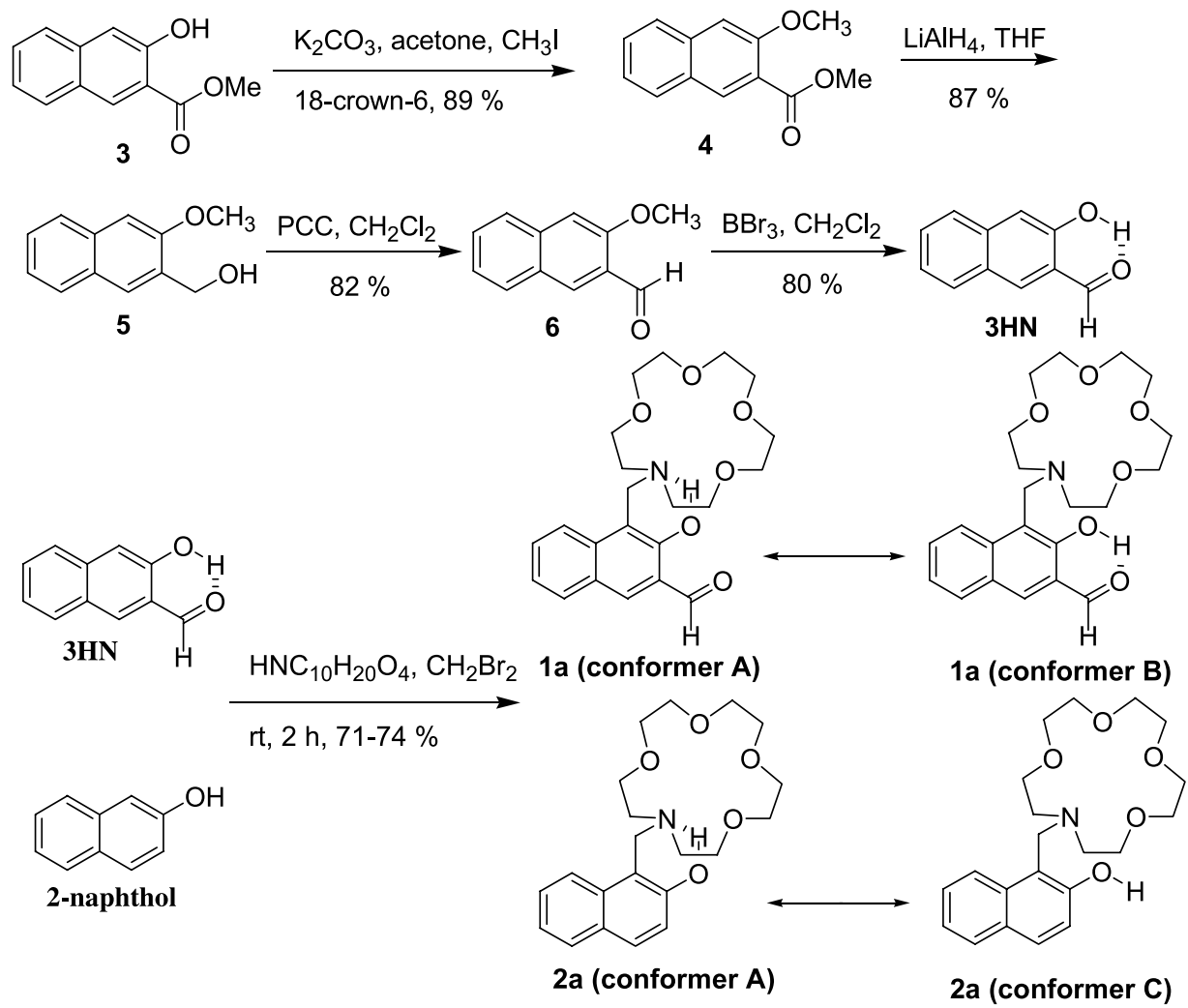

Scheme 2. The synthetic scheme for compounds 1a and 2a, and their possible conformers.

\section{Experimental}

\subsection{General}

All reactions were performed under nitrogen atmosphere. Solvents were distilled from appropriate drying agents prior to use. Commercially available reagents were used without further purification unless otherwise stated. All reactions were monitored by TLC with Macherey-Nagel pre-coated glassic sheets $\left(0.20 \mathrm{~mm}\right.$ with fluorescent indicator $\left.\mathrm{UV}_{254}\right)$. Compounds were visualized with UV light at 254 and $365 \mathrm{~nm}$. Flash column chromatography was carried out using silica gel from Merck (230-400 mesh). ${ }^{1} \mathrm{H}$ NMR and ${ }^{13} \mathrm{C} \mathrm{NMR}$ in $\mathrm{CDCl}_{3}$ were recorded using a Varian (Unity Plus 400) spectrometer at 400 and $100 \mathrm{MHz}$, respectively. FAB-mass spectroscopy were collected on a JMS-700 double focusing mass spectrometer (JEOL, Tokyo, Japan) with a resolution of 3000 and 8000 for LR and HR 
FAB-mass spectra. The source accelerating voltage was operated at $10 \mathrm{kV}$ with Xe gun for FAB-mass spectra, using 3-nitrobenzyl alcohol as matrix.

\subsubsection{3-Methoxy-naphthalene-2-carboxylic acid methyl} ester (4). To a suspension of potassium carbonate $(2.7 \mathrm{~g}$, $19.8 \mathrm{mmol})$ in acetone $(10 \mathrm{~mL})$ was added 2-hydroxy-3naphthoic acid methyl ester $(2.0 \mathrm{~g}, 9.9 \mathrm{mmol})$ and catalyst amount of 18 -crown-6 ether $(0.3 \mathrm{~g}, 1.0 \mathrm{mmol})$, followed by addition of methyl iodide $(2.1 \mathrm{~g}, 14.9 \mathrm{mmol})$ under nitrogen. The reaction mixture was subjected to reflux for $12 \mathrm{~h}$. The mixture was cooled and the solvent was removed via reduced pressure. The product was then extracted with $\mathrm{CH}_{2} \mathrm{Cl}_{2}$. Subsequently, the organic layer was dried with $\mathrm{MgSO}_{4}$ and filtered, and the solvent was removed in vacuum. The residue was purified by column chromatography (eluent: EtOAc/hexane $(1: 10 \mathrm{v} / \mathrm{v}))$, yielding compound 4, $(1.9 \mathrm{~g}, 89 \%) .{ }^{1} \mathrm{H} \mathrm{NMR}\left(\mathrm{CDCl}_{3}, 400 \mathrm{MHz}\right) \delta 3.9(\mathrm{~s}$, $3 \mathrm{H}), 3.98(\mathrm{~s}, 3 \mathrm{H}), 7.18(\mathrm{~s}, 1 \mathrm{H}), 7.34(\mathrm{td}, J=8.0,1.2 \mathrm{~Hz}, 1 \mathrm{H})$, $7.50(\mathrm{td}, J=8.0,1.2 \mathrm{~Hz}, 1 \mathrm{H}), 7.72(\mathrm{~d}, J=8.4 \mathrm{~Hz}, 1 \mathrm{H}), 7.79$ $(\mathrm{d}, J=8.0 \mathrm{~Hz}, 1 \mathrm{H}) ;{ }^{13} \mathrm{C} \mathrm{NMR}\left(\mathrm{CDCl}_{3}, 100 \mathrm{MHz}\right) \delta 52.3$ $\left(\mathrm{CH}_{3}\right), 56.0\left(\mathrm{CH}_{3}\right), 106.7(\mathrm{CH}), 114.9(\mathrm{C}), 121.6(\mathrm{C}), 124.3$ $(\mathrm{CH}), 126.3(\mathrm{CH}), 127.4(\mathrm{C}), 128.3(\mathrm{CH}), 128.5(\mathrm{CH}), 132.6$ (CH), 135.9 (C), 155.5 (C), 166.5 (C); IR (neat) 3062, 2956, 2837, 1732, 1640, 1590, 1507, 1470, 1428, $1337 \mathrm{~cm}^{-1}$; FAB-MS $m / z$ (rel intensity) $217\left(\mathrm{M}^{+}+1,100 \%\right)$; HRMS (FAB) Calcd for $\mathrm{C}_{13} \mathrm{H}_{12} \mathrm{O}_{3} 216.0786$, found 216.0788.

2.1.2. (3-Methoxy-naphthalen-2-yl)-methanol (5). To a suspension of $\mathrm{LiAlH}_{4}(0.7 \mathrm{~g}, 17.13 \mathrm{mmol})$ in dry THF $(40 \mathrm{~mL})$ was added 3-Methoxy-naphthalene-2-carboxylic acid methyl ester $(1.9 \mathrm{~g}, 8.7 \mathrm{mmol})$ in dry THF $(10 \mathrm{~mL})$ in ice bath. The mixture was stirred at room temperature for $6 \mathrm{~h}$. The reaction was then quenched with water. The product extracted from $\mathrm{CH}_{2} \mathrm{Cl}_{2}$ was washed with water and dried with $\mathrm{MgSO}_{4}$. After filtration $\mathrm{CH}_{2} \mathrm{Cl}_{2}$ was removed by a rotavapor under reduced pressure and the residue was purified by column chromatography (eluent: EtOAc/hexane $(1: 5 \mathrm{v} / \mathrm{v}))$, affording compound 5 as a white solid $(1.4 \mathrm{~g}$, $87 \%) .{ }^{1} \mathrm{H} \mathrm{NMR}\left(\mathrm{CDCl}_{3}, 400 \mathrm{MHz}\right) \delta 2.10(\mathrm{~s}, 1 \mathrm{H}), 3.96(\mathrm{~s}$, $3 \mathrm{H}), 4.81(\mathrm{~s}, 2 \mathrm{H}), 7.11(\mathrm{~s}, 1 \mathrm{H}), 7.33(\mathrm{td}, J=7.8,1.0 \mathrm{~Hz}, 1 \mathrm{H})$, $7.42(\mathrm{td}, J=8.0,1.0 \mathrm{~Hz}, 1 \mathrm{H}), 7.71-7.76(\mathrm{~m}, 3 \mathrm{H}) ;{ }^{13} \mathrm{C} \mathrm{NMR}$ $\left(\mathrm{CDCl}_{3}, 100 \mathrm{MHz}\right) \delta 55.4\left(\mathrm{CH}_{2}\right), 62.5\left(\mathrm{CH}_{3}\right), 105.1(\mathrm{CH})$, $123.8(\mathrm{CH}), 126.2(\mathrm{CH}), 126.3(\mathrm{CH}), 127.4(\mathrm{CH}), 127.5$ (CH), $128.5(\mathrm{C}), 130.3(\mathrm{C}), 134.0(\mathrm{C}), 155.7$ (C); IR (neat) 3590, 3406, 3058, 2952, 1644, 1608, 1512, 1465, 1436, 1401, $1340 \mathrm{~cm}^{-1}$; FAB-MS $\mathrm{m} / \mathrm{z}$ (rel intensity) $188\left(\mathrm{M}^{+}\right.$, $100 \%$ ); HRMS (FAB) Calcd for $\mathrm{C}_{12} \mathrm{H}_{12} \mathrm{O}_{2}$ 188.0837, found 188.0839 .

2.1.3. 3-Methoxy-naphthalene-2-carbaldehyde (6). A solution of (3-methoxy-naphthalen-2-yl)-methanol ( $1.3 \mathrm{~g} 6.7 \mathrm{mmol})$ in $\mathrm{CH}_{2} \mathrm{Cl}_{2}$ was added dropwise at $0{ }^{\circ} \mathrm{C}$ to a mixture of pyridinium chlorochromate (PCC, $2.2 \mathrm{~g}$ $10.0 \mathrm{mmol})$, sodium acetate $(0.8 \mathrm{~g} 10.0 \mathrm{mmol})$ and $4 \AA$ molecular sieve $(2.2 \mathrm{~g})$ in $\mathrm{CH}_{2} \mathrm{Cl}_{2}$. The mixture was stirred for $40 \mathrm{~min}$ under inert atmosphere. The solvent was removed under reduced pressure, and the residue was dissolved in ether and filtered. The product was purified by column chromatography. Elution with EtOAc/hexane $(1: 10 \mathrm{v} / \mathrm{v})$ afforded compound $\mathbf{6}$ as yellow oil $(1.0 \mathrm{~g}$, $82 \%) .{ }^{1} \mathrm{H}$ NMR $\left(\mathrm{CDCl}_{3}, 400 \mathrm{MHz}\right) \delta 4.01(\mathrm{~s}, 3 \mathrm{H}), 7.17(\mathrm{~s}$, $1 \mathrm{H}), 7.36(\mathrm{td}, J=8.0,1.0 \mathrm{~Hz}, 1 \mathrm{H}), 7.52(\mathrm{td}, J=8.0,1.0 \mathrm{~Hz}$,
1H), $7.72(\mathrm{~d}, J=8.0 \mathrm{~Hz}, 1 \mathrm{H}), 7.86(\mathrm{~d}, J=7.6 \mathrm{~Hz}, 1 \mathrm{H}), 8.34$ $(\mathrm{s}, 1 \mathrm{H}), 10.55(\mathrm{~s}, 1 \mathrm{H}) ;{ }^{13} \mathrm{C} \mathrm{NMR}\left(\mathrm{CDCl}_{3}, 100 \mathrm{MHz}\right) \delta 55.8$ $\left(\mathrm{CH}_{3}\right), 106.1(\mathrm{CH}), 124.3(\mathrm{CH}), 125.3(\mathrm{C}), 126.2(\mathrm{CH})$, $127.4(\mathrm{C}), 128.8(\mathrm{CH}), 129.5(\mathrm{CH}), 130.6(\mathrm{CH}), 137.1(\mathrm{C})$, 157.0 (C), 189.4 (CH); IR (KBr) 3064, 2994, 2880, 1700, 1632, 1602, 1470, 1434, 1406, $1346 \mathrm{~cm}^{-1}$; FAB-MS m/z (rel intensity), $187\left(\mathrm{M}^{+}+1,100 \%\right)$; HRMS (FAB) Calcd for $\mathrm{C}_{12} \mathrm{H}_{10} \mathrm{O}_{2}$ 186.0681, found 186.0684.

2.1.4. 3-Hydroxy-naphthalene-2-carbaldehyde (3HN). Under inert atmosphere, a solution of $\mathrm{BBr}_{3}(0.52 \mathrm{~g}$, $3.2 \mathrm{mmol})$ in anhydrous $\mathrm{CH}_{2} \mathrm{Cl}_{2}(5 \mathrm{~mL})$ was added at $0{ }^{\circ} \mathrm{C}$ to a solution of 3-methoxynaphthalene-2-carbaldehyde $(0.5 \mathrm{mg}, 2.7 \mathrm{mmol})$ in anhydrous $\mathrm{CH}_{2} \mathrm{Cl}_{2}(5 \mathrm{~mL})$. The mixture was stirred at room temperature for $1 \mathrm{~h}$, and then the reaction was quenched with $1 \mathrm{~N} \mathrm{NaHCO}_{3}$ aqueous solution. The product was extracted with $\mathrm{CH}_{2} \mathrm{Cl}_{2}$, and the resulting organic layers were dried with $\mathrm{MgSO}_{4}$. After evaporation of the solvent under reduced pressure, the crude mixture was purified by column chromatography (eluent: EtOAc/hexane $(1: 20 \mathrm{v} / \mathrm{v}))$, yielding $3 \mathrm{HN}$ in $0.37 \mathrm{mg}(80 \%)$. ${ }^{1} \mathrm{H} \mathrm{NMR}\left(\mathrm{CDCl}_{3}, 400 \mathrm{MHz}\right) \delta 7.23(\mathrm{~s}, 1 \mathrm{H}), 7.36(\mathrm{t}, J=$ $8.4 \mathrm{~Hz}, 1 \mathrm{H}), 7.55(\mathrm{t}, J=8.4 \mathrm{~Hz}, 1 \mathrm{H}), 7.70(\mathrm{~d}, J=8.4 \mathrm{~Hz}$, $1 \mathrm{H}), 7.85(\mathrm{~d}, J=8.4 \mathrm{~Hz}, 1 \mathrm{H}), 8.13(\mathrm{~s}, 1 \mathrm{H}), 10.06(\mathrm{~s}, 1 \mathrm{H})$, $10.30(\mathrm{~s}, 1 \mathrm{H}) ;{ }^{13} \mathrm{C} \mathrm{NMR}\left(\mathrm{CD}_{3} \mathrm{OD}, 100 \mathrm{MHz}\right) \delta 111.9(\mathrm{CH})$, $122.1(\mathrm{C}), 124.3(\mathrm{CH}), 126.6(\mathrm{CH}), 127.3(\mathrm{C}), 129.2(\mathrm{CH})$, $130.1(\mathrm{CH}), 137.7(\mathrm{CH}), 138.0(\mathrm{C}), 155.6(\mathrm{C}), 196.4(\mathrm{CH})$; IR (KBr) 3256, 3064, 2985, 2856, 1674, 1518, 1458, 1417, 1388, 1358, $1308 \mathrm{~cm}^{-1}$; FAB-MS $\mathrm{m} / \mathrm{z}$ (rel intensity) 172 $\left(\mathrm{M}^{+}, 100 \%\right)$; HRMS (FAB) Calcd for $\mathrm{C}_{11} \mathrm{H}_{8} \mathrm{O}_{2} 172.0524$, found 172.0528 .

\subsubsection{3-Hydroxy-4-(1,4,7,10-tetraoxa-13-azacyclopenta-} dec-13-ylmethyl)naphthalene-2-carbaldehyde (1a). A mixture of 1 -aza-15-crown-5 ether $(0.6 \mathrm{~g}, 2.8 \mathrm{mmol})$ and dibromomethane $(1.1 \mathrm{~g}, 11.4 \mathrm{mmol})$ was stirred at room temperature for $4 \mathrm{~h}$ under inert atmosphere. A solution containing 3-hydroxy-naphthalene-2-carbaldehyde $(0.1 \mathrm{~g}$, $0.71 \mathrm{mmol})$ in $\mathrm{CH}_{2} \mathrm{Cl}_{2}(2 \mathrm{~mL})$ was added and the mixture was stirred at room temperature for $6 \mathrm{~h}$. The solvent was removed under reduced pressure, and the residue was dissolved in diethyl ether and filtered. The product was purified by column chromatography (eluent: methanol/ dichloromethane $(2: 98 \mathrm{v} / \mathrm{v}))$, yielding compound $\mathbf{1 a}$ as yellow oil (203.1 mg, $0.5 \mathrm{mmol}, 71 \%) .{ }^{1} \mathrm{H} \mathrm{NMR}\left(\mathrm{CDCl}_{3}\right.$, $400 \mathrm{MHz}) \delta 2.90(\mathrm{t}, J=5.2 \mathrm{~Hz}, 4 \mathrm{H}), 3.60-3.73(\mathrm{~m}, 16 \mathrm{H})$, $4.25(\mathrm{~s}, 2 \mathrm{H}), 7.28(\mathrm{t}, J=8.0 \mathrm{~Hz}, 1 \mathrm{H}), 7.49(\mathrm{t}, J=8.2 \mathrm{~Hz}$, $1 \mathrm{H}), 7.82(\mathrm{~d}, J=8.8 \mathrm{~Hz}, 2 \mathrm{H}), 8.23(\mathrm{~s}, 1 \mathrm{H}), 10.58(\mathrm{~s}, 1 \mathrm{H})$; ${ }^{13} \mathrm{C} \mathrm{NMR}\left(\mathrm{CDCl}_{3}, 100 \mathrm{MHz}\right) \delta 53.6\left(\mathrm{CH}_{2}\right), 54\left(\mathrm{CH}_{2}\right), 68.7$ $\left(2 \times \mathrm{CH}_{2}\right), 70.3\left(4 \times \mathrm{CH}_{2}\right), 70.8\left(2 \times \mathrm{CH}_{2}\right), 114.1(\mathrm{C}), 121.3$ $(\mathrm{CH}), 123.2(\mathrm{CH}), 124.4(\mathrm{C}), 127.0(\mathrm{C}), 129.0(\mathrm{CH}), 130.4$ $(\mathrm{CH}), 130.9(\mathrm{CH}), 135.9(\mathrm{C}), 157.4(\mathrm{C}), 191.6(\mathrm{CH})$; IR (KBr) 3418, 3058, 2873, 1692, 1668, 1630, 1622, 1458, $1399,1364 \mathrm{~cm}^{-1}$; FAB-MS m/z (rel intensity) $404\left(\mathrm{M}^{+}+\right.$ 1, 100\%); HRMS (FAB) Calcd for $\mathrm{C}_{22} \mathrm{H}_{29} \mathrm{NO}_{6} 403.1995$, found 403.1999; Anal. Calcd for $\mathrm{C}_{22} \mathrm{H}_{29} \mathrm{NO}_{6}$ : C, 65.49; $\mathrm{H}$, 7.24; N, 3.47. Found: C, 65.44; H, 7.29; N, 3.47.

2.1.6. 1-(1,4,7,10-Tetraoxa-13-azacyclopentadec-13ylmethyl)-2-naphthol (2a). A mixture of 1-aza-15-crown5 ether $(0.6 \mathrm{~g}, 2.8 \mathrm{mmol})$ and dibromomethane $(1.9 \mathrm{~g}$, $11.0 \mathrm{mmol}$ ) was stirred at room temperature for $4 \mathrm{~h}$ under inert atmosphere. A solution of 2-naphthol $(0.1 \mathrm{~g}$, 
$0.69 \mathrm{mmol})$ in $\mathrm{CH}_{2} \mathrm{Cl}_{2}(1 \mathrm{~mL})$ was added and the mixture was stirred at room temperature for $5 \mathrm{~h}$. After removing $\mathrm{CH}_{2} \mathrm{Cl}_{2}$ under reduced pressure, the residue was dissolved in diethyl ether and filtered. The product was then purified by column chromatography (eluent: ethyl acetate/hexane $(1: 1 \mathrm{v} / \mathrm{v}))$, yielding compound $2 \mathbf{2 a}(194.1 \mathrm{mg}, 74 \%) .{ }^{1} \mathrm{H}$ NMR $\left(\mathrm{CDCl}_{3}, 400 \mathrm{MHz}\right) \delta 2.93(\mathrm{t}, J=5.2 \mathrm{~Hz}, 4 \mathrm{H}), 3.60$ $3.71(\mathrm{~m}, 16 \mathrm{H}), 4.27(\mathrm{~s}, 2 \mathrm{H}), 7.08(\mathrm{~d}, J=8.8 \mathrm{~Hz}, 1 \mathrm{H}), 7.25(\mathrm{t}$, $J=6.8 \mathrm{~Hz}, 1 \mathrm{H}), 7.41(\mathrm{td}, J=7.6,1.2 \mathrm{~Hz}, 1 \mathrm{H}), 7.65(\mathrm{~d}, J=$ $8.4,1.6 \mathrm{~Hz}, 1 \mathrm{H}), 7.72(\mathrm{~d}, J=8.4 \mathrm{~Hz}, 1 \mathrm{H}), 7.82(\mathrm{~d}, J=$ $8.8 \mathrm{~Hz}, 1 \mathrm{H}) ;{ }^{13} \mathrm{C} \mathrm{NMR}\left(\mathrm{CDCl}_{3}, 100 \mathrm{MHz}\right) \delta 54.3\left(\mathrm{CH}_{2}\right)$, $54.7\left(\mathrm{CH}_{2}\right), 68.8\left(\mathrm{CH}_{2}\right), 70.3\left(\mathrm{CH}_{2}\right), 70.3\left(4 \times \mathrm{CH}_{2}\right), 70.7$ $\left(\mathrm{CH}_{2}\right), 111.9(\mathrm{C}), 119.3(\mathrm{CH}), 120.8(\mathrm{CH}), 122.2(\mathrm{CH})$, $126.1(\mathrm{CH}), 128.3(\mathrm{C}), 128.7(\mathrm{CH}), 128.0(\mathrm{CH}), 132.6(\mathrm{C})$, 156.4 (C); IR (KBr, neat) $\left(\mathrm{cm}^{-1}\right)$ : $3488,3060,2874,1676$, 1626, 1602, 1526, 1474, 1410, 1353, 1272, 1238, 1128; FAB-MS $m / z$ (rel intensity) $376\left(\mathrm{M}^{+}+1,100 \%\right)$; HRMS (FAB) Calcd for $\mathrm{C}_{21} \mathrm{H}_{29} \mathrm{NO}_{5}$ 375.2046, found 375.2049; Anal. Calcd for $\mathrm{C}_{21} \mathrm{H}_{29} \mathrm{NO}_{5}$ : C, 67.18; H, 7.79; N, 3.73. Found: C, 65.15; H, 7.76; N, 3.77.

\subsection{Spectroscopy and dynamics measurements}

Steady-state absorption and emission spectra were recorded by a Hitachi (U-3310) spectrophotometer and an Edinburgh (FS920) fluorimeter, respectively. The excitation light source of the fluorimeter has been corrected by the Rodamine B spectrum. In addition, the wavelengthdependent characteristics of the monochromator and photomultiplier have been calibrated by recording the scattered light spectrum of the corrected excitation light from a diffused cell in the range of $220-700 \mathrm{~nm}$.

For determining fluorescence quantum yields and relaxation dynamics of the studied compounds, sample solutions were degassed by three freeze-pump-thaw cycles under vigorous stirring condition. Quinine sulfate/1.0 $\mathrm{N} \mathrm{H}_{2} \mathrm{SO}_{4}$ was used as a reference for the quantum yield measurement, assuming a yield of 0.564 with $360 \mathrm{~nm}$ excitation. Nanosecond lifetime studies were performed by an Edinburgh FL 900 photoncounting system with a hydrogen-filled/or a nitrogen lamp as the excitation source. Data were analyzed using the nonlinear least squares procedure in combination with an iterative convolution method, which allows partial removal of the instrument time broadening and consequently renders a temporal resolution of $\sim 200$ ps. A Suntex SP-701 pHmeter was used for the $\mathrm{pH}$ titration study.

\section{Results and discussion}

Similar to that of conformer $\mathbf{A}$ in DMHN, ${ }^{8}$ the emission of 1a revealed strong solvent-polarity dependence, being red shifted from $505 \mathrm{~nm}$ in cyclohexane to $585 \mathrm{~nm}$ in $\mathrm{CH}_{3} \mathrm{CN}$. The spectral shift of the fluorescence upon increasing solvent polarity depends on the difference in permanent dipole moments between ground $\left(\mu_{\mathrm{g}}\right)$ and excited $\left(\mu_{\mathrm{e}}\right)$ states, which can be quantitatively expressed based on Lippert equation ${ }^{11}$ expressed in Eq. 1

$\tilde{\nu}_{\mathrm{f}}=\tilde{\nu}_{\mathrm{f}}^{\mathrm{vac}}-\left(\frac{2\left|\vec{\mu}_{\mathrm{e}}-\vec{\mu}_{\mathrm{g}}\right|^{2}}{h c a_{0}^{3}}\right)\left(\frac{\varepsilon-1}{2 \varepsilon+1}\right)$

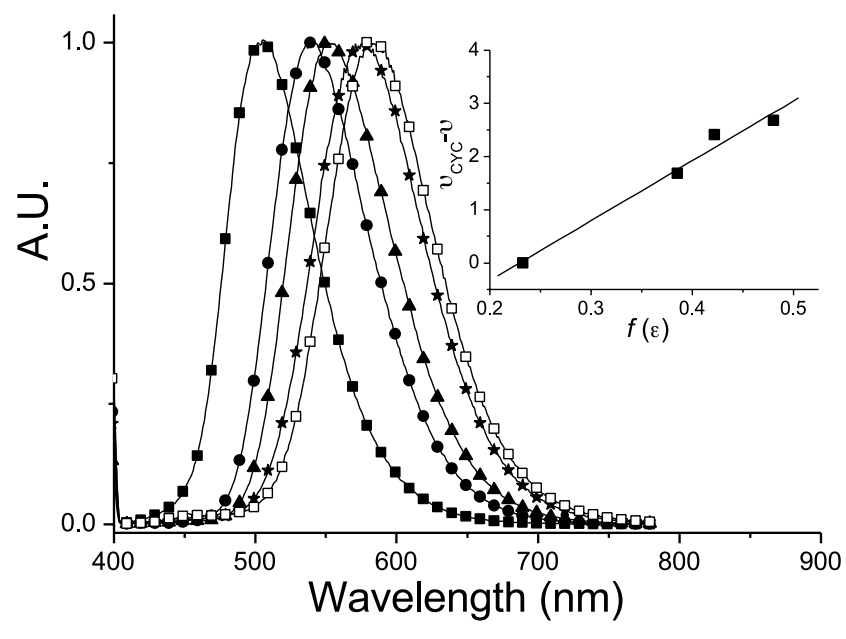

Figure 1. The emission spectra of $\mathbf{1 a}$ in cyclohexane (- $-\mathbf{-})$, benzene (- - ), ethyl acetate $(-\boldsymbol{\Delta}-)$, dichloromethane $(-\star-)$ and acetonitrile $(-\square-)$. The emission intensity has been normalized. Insert: the plot of $\tilde{\nu}_{\mathrm{f}}^{\text {cyc }}-\nu_{\mathrm{f}}$ versus $f(\varepsilon)=(\varepsilon-1) /(2 \varepsilon+1)$ in various solvents.

where $a_{0}$ and $\varepsilon$ denote the cavity radius and solvent dielectric constant, respectively, $\tilde{\nu}_{\mathrm{f}}$ and $\tilde{\nu}_{\mathrm{f}}^{\mathrm{vac}}$ represent the fluorescence peak frequency (in $\mathrm{cm}^{-1}$ ) in solvent studied and in vacuum, respectively. In this study, $\tilde{\nu}_{\mathrm{f}}^{\mathrm{vac}}$ can be replaced by the peak frequency in cyclohexane $\left(\tilde{\nu}_{\mathrm{f}}^{\text {cyc }}\right)$ if one neglects the induced dipole interaction. As shown in the insert of Figure 1, the plot of $\tilde{\nu}_{\mathrm{f}}^{\text {cyc }}-\nu_{\mathrm{f}}$ versus $f(\varepsilon)=(\varepsilon-1) /$ $(2 \varepsilon+1)$ is sufficiently linear, and a slope of as large as $11,200 \mathrm{~cm}^{-1}$ is deduced. $a_{0}$ in Eq. 1 was estimated to be $6.4 \AA$ via the Hartree Fock theories with $6-31 \mathrm{G}^{\prime}\left(\mathrm{d}^{\prime}, \mathrm{p}^{\prime}\right)$ basis sets. Accordingly, the change in dipole moment between ground and excited states was deduced to be as large as 17.2 debye.

The results lead us to ascribe the $585 \mathrm{~nm}$ emission in $\mathrm{CH}_{3} \mathrm{CN}$ to a zwitterionic species resulting from $\mathrm{O}-\mathrm{H} \cdots \mathrm{N} \rightarrow$ $\mathrm{O}^{-} \cdots \mathrm{HN}^{+}$ESIPT. In contrast to the existence of conformers A and $\mathbf{B}$ for DMHN, as supported by the significant difference between absorption and excitation spectrum monitored at zwitterion emission, ${ }^{8}$ the excitation spectrum of $1 \mathrm{a}$ in $\mathrm{CH}_{3} \mathrm{CN}$ is identical to the absorption spectrum. The results indicate that the $\mathrm{O}-\mathrm{H} \cdots \mathrm{N}$ intramolecular $\mathrm{HB}$ conformer $\mathbf{A}$ is the dominant species in 1a. Further support was given by the lack of resolution of any keto-tautomer emission at $>700 \mathrm{~nm}$ predicted according to the ESIPT mechanism in conformer B of DMHN. ${ }^{8}$ The more stable conformer $\mathbf{A}$ in $\mathbf{1 a}$ can qualitatively be rationalized by additional $\mathrm{HB}$ interactions between $-\mathrm{O}-\mathrm{H}$ and ether oxygens. This viewpoint is also supported by a semiempirical PM3 approach (see Fig. 2), estimating conformer A of $\mathbf{1 a}$ to be energetically lower than conformer $\mathbf{B}$ by $\sim 1.6 \mathrm{kcal} / \mathrm{mol}$. In addition, the dipole moment of 5.52 debye calculated for conformer $\mathbf{A}$ of $\mathbf{1 a}$ is larger than that of $\mathbf{B}$ (3.75 debye). Accordingly, it is reasonable to expect the dominant conformer $\mathbf{A}$ in the strong polar solvent such as $\mathrm{CH}_{3} \mathrm{CN}$.

The corresponding absorption and fluorescence titration spectra in $\mathrm{CH}_{3} \mathrm{CN}$ upon the addition of $\mathrm{Na}^{+}$to $1 \mathrm{a}$ are shown in Figures 3 and 4, respectively. Table 1 lists the 


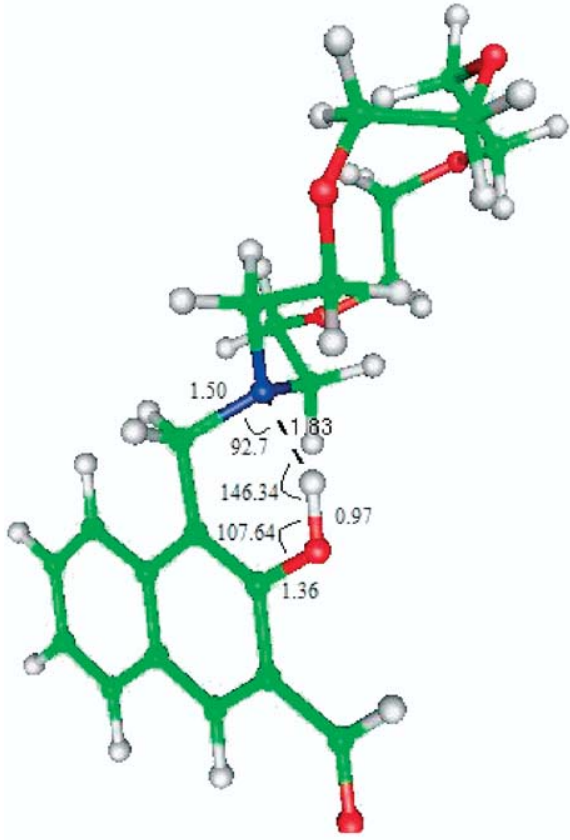

1a (conformer A)

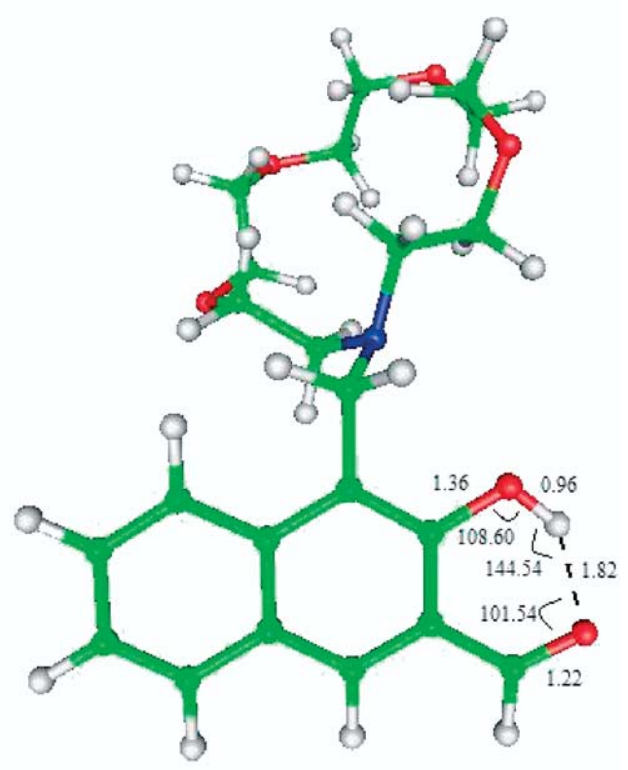

1a (conformer B)

Figure 2. Two geometry-optimized (PM3 method) hydrogen-bonding conformers of 1a, and the respective critical bond distance (in $\AA$ ) and angle (in degree) involved in the intramolecular hydrogen bond.

photopysical properties of 1a and 2a and their associated metal ion complexes in $\mathrm{CH}_{3} \mathrm{CN}$. Increasing the $\left[\mathrm{Na}^{+}\right]$led to a hypsochromic shift of the absorption profile, in which the appearance of isosbestic points at $\sim 360$ and $315 \mathrm{~nm}$ verifies a two-species equilibrium. Thus, the plot of the relationship between the measured absorbance $A$ as a function of the added $\mathrm{NaClO}_{4}$ concentration, $C_{\mathrm{g}}$, can be expressed by Eq. $2^{12}$

$\frac{A_{0}}{A-A_{0}}=\left(\frac{\varepsilon_{\mathrm{M}}}{\varepsilon_{\mathrm{c}}-\varepsilon_{\mathrm{M}}}\right)\left[\frac{1}{K_{\mathrm{a}}\left[C_{\mathrm{g}}\right]}+1\right]$

where $\varepsilon_{\mathbf{M}}$ and $\varepsilon_{\mathrm{c}}$ are molar extinction coefficients of 1a

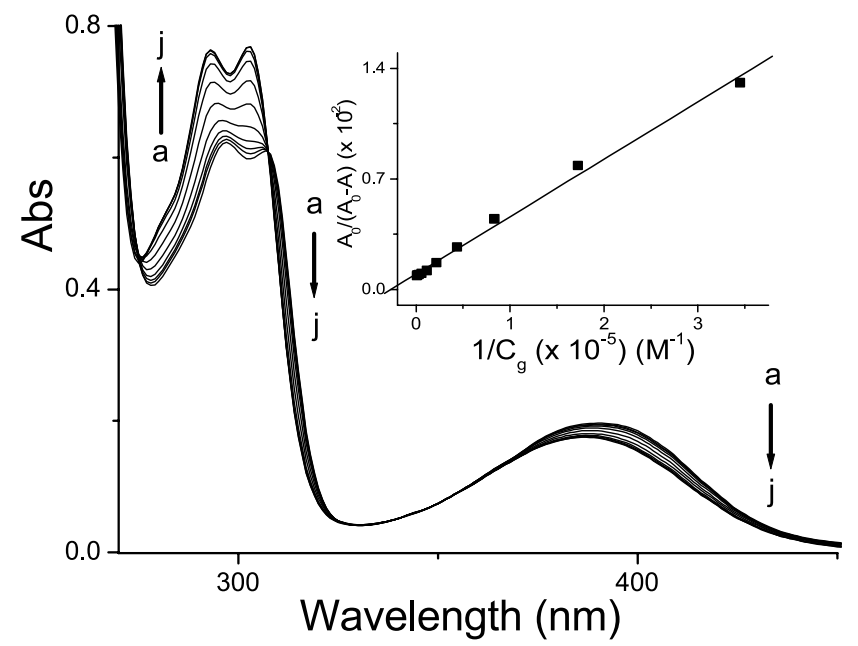

Figure 3. Absorption spectra of $1 \mathrm{a}\left(3.2 \times 10^{-5} \mathrm{M}\right)$ in $\mathrm{CH}_{3} \mathrm{CN}$ by adding $\mathrm{NaClO}_{4}$ concentrations $\left(C_{\mathrm{g}}\right.$ ) of (a) 0 , (b) 1 , (c) 2, (d) 4, (e) 8, (f) 16, (g) 30, (h) 60 , (i) 120 , (j) 240 equiv ( 1 equiv $=2.9 \times 10^{-6} \mathrm{M}$ ). Insert: the plot of $A_{0} / A_{0}-A$ against $1 / C_{\mathrm{g}}$ at $400 \mathrm{~nm}$. and $\mathbf{1 a} / \mathrm{Na}^{+}$complex, respectively, at a selected wavelength. $A_{0}$ denotes the absorbance of the free $\mathbf{1 a}$ at that specific wavelength. The $1: 1 \quad \mathbf{1 a} / \mathrm{Na}^{+}$complexation was supported by a straight-line plot for the ratio of absorbance, $A_{0} /\left(A_{0}-A\right)$, versus $1 /\left[\mathrm{Na}^{+}\right]$throughout the titration (insert of Fig. 3), and an association constant of as high as $(2.5 \pm 0.5) \times 10^{4} \mathrm{M}^{-1}$ was deduced in $\mathrm{CH}_{3} \mathrm{CN}$.

Drastic changes on the $\mathrm{Na}^{+}$fluorescence titration spectra were also observed, in which the $585 \mathrm{~nm}$ zwitterion emission decreased with increasing $\mathrm{Na}^{+}$concentrations (Fig. 4). The relationship between the measured

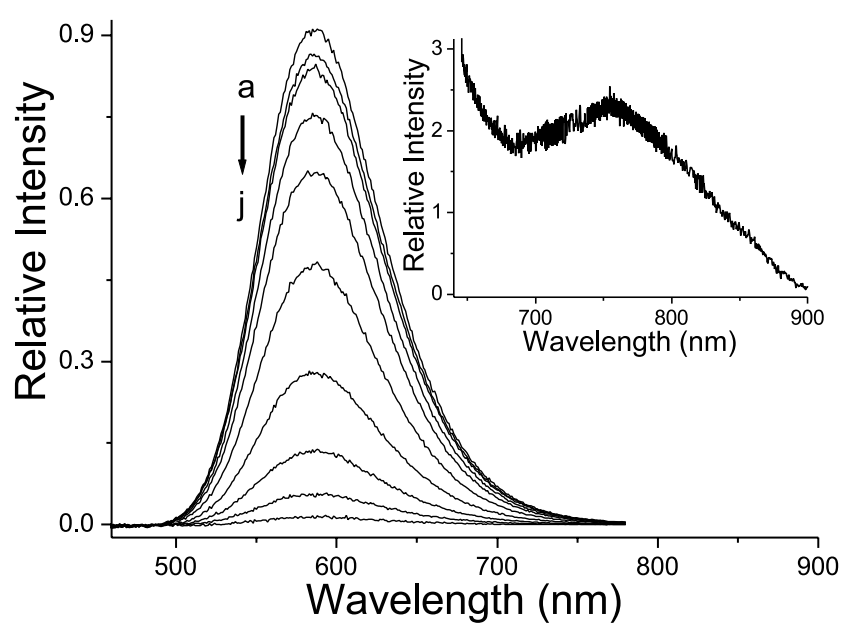

Figure 4. Fluorescence spectra of $1 \mathrm{a}\left(3.2 \times 10^{-5} \mathrm{M}\right)$ in $\mathrm{CH}_{3} \mathrm{CN}$ by adding $\mathrm{NaClO}_{4}$ concentrations $\left(C_{\mathrm{g}}\right.$ ) of (a) 0 , (b) 1 , (c) 2, (d) 4, (e) 8, (f) 16, (g) 30 , (h) 60 , (i) 120 , (j) 240 equiv $\left(1\right.$ equiv $\left.=2.9 \times 10^{-6} \mathrm{M}\right), \lambda_{\mathrm{ex}}: 400 \mathrm{~nm}$. Insert: The spectrum of $\mathbf{1 a}$ at $>700 \mathrm{~nm}$ by adding $10^{-3} \mathrm{M} \mathrm{NaClO}_{4}$. 
Table 1. The photophysical properties of ion-free $1 \mathbf{a}$ and $2 \mathbf{a}$ and the association constants of various $\mathbf{1 a} /$ metal ion and $\mathbf{2 a} /$ metal ion complexes in $\mathrm{CH}_{3} \mathrm{CN}$

\begin{tabular}{ccccc}
\hline & $\begin{array}{c}\text { Absorption } \\
\lambda_{\max }(\mathrm{nm})\end{array}$ & $\begin{array}{c}\text { Fluorescence } \\
\lambda_{\max }(\mathrm{nm}), \tau_{\mathrm{f}}\end{array}$ & \multicolumn{2}{c}{ Association constant $K_{\mathrm{a}}\left(\mathrm{M}^{-1}\right)$} \\
\cline { 3 - 5 } & & & $\mathrm{Na}^{+}$ & $\mathrm{Ca}^{2+}$ \\
\hline $\mathbf{1 a}$ & 390 & $585(4.7 \mathrm{~ns})$, & $2.3 \times 10^{4}$ & $3.8 \times 10^{4}$ \\
& & $730(520 \mathrm{fs})$ & & $1.2 \times 10^{4}$ \\
$\mathbf{2 a}$ & 327 & $355(4.6 \mathrm{~ns})$, & $5.5 \times 10^{3}$ & \\
& & $432(4.3 \mathrm{~ns})$ & & \\
\hline
\end{tabular}

fluorescence intensity $F$ and $C_{\mathrm{g}}$ in a selected wavelength can be expressed by Eq. $3^{12}$

$\frac{F_{0}}{F-F_{0}}=\frac{\Phi_{\mathrm{M}} \varepsilon_{\mathrm{M}}}{\left(\Phi_{\mathrm{C}} \varepsilon_{\mathrm{C}}-\Phi_{\mathrm{M}} \varepsilon_{\mathrm{M}}\right)}\left(\frac{1}{K_{\mathrm{a}} C_{\mathrm{g}}}+1\right)$

where $F_{0}$ denotes the fluorescence intensity of free 1a. $\Phi_{\mathrm{M}}$ and $\Phi_{\mathrm{C}}$ are fluorescence quantum yields of the free $\mathbf{1 a}$ and complex, respectively, which are assumed to be constant throughout the titration. A linear plot for the ratio of fluorescence intensity, $F_{0} /\left(F-F_{0}\right)$, versus $1 /\left[\mathrm{Na}^{+}\right]$for the $585 \mathrm{~nm}$ band reconfirmed the 1:1 complex formation, and $K_{\mathrm{a}}$ was deduced to be $(2.3 \pm 0.3) \times 10^{4} \mathrm{M}^{-1}$. Upon the addition of $\left[\mathrm{Na}^{+}\right]$of $>10^{-3} \mathrm{M}$, in which $>99 \%$ of $1 \mathrm{a} / \mathrm{Na}^{+}$ complex is formed, a weak emission band $\left(\Phi_{\mathrm{f}}<10^{-4}\right)$ maximized at $\sim 730 \mathrm{~nm}$ was observed (see insert of Fig. 4). The mechanism of complexation can thus be rationalized by the rupture of the $\mathrm{O}-\mathrm{H} \cdots \mathrm{N}$ hydrogen bond due to the usage of lone pair electrons on the nitrogen atom upon formation of the $1 \mathrm{a} / \mathrm{Na}^{+}$complex, resulting in switching the intramolecular $\mathrm{HB}$ sites from $\mathrm{O}-\mathrm{H} \cdots \mathrm{N}$ (conformer A) to $\mathrm{O}-\mathrm{H} \cdots \mathrm{O}=\mathrm{C}$ (conformer $\mathbf{B}$ ). ESIPT takes place in the $\mathrm{Na}^{+} /$ conformer $\mathbf{B}$ complex, giving rise to a keto-tautomer $730 \mathrm{~nm}$ emission.

In contrast to a unique, zwitterionic emission band in 1a, 2a exhibits dual emission maximized at 355 (4.6 ns) and $432 \mathrm{~nm}\left(\tau_{\mathrm{f}}=4.3 \mathrm{~ns}\right)$ (see Fig. 5). Similar to that assigned for 1-diethylaminomethyl-2-naphthol, ${ }^{13}$ the $432 \mathrm{~nm}$ emission can be ascribed to a zwitterion emission resulting from ESIPT. Accordingly, the $355 \mathrm{~nm}$ band, being a mirror image

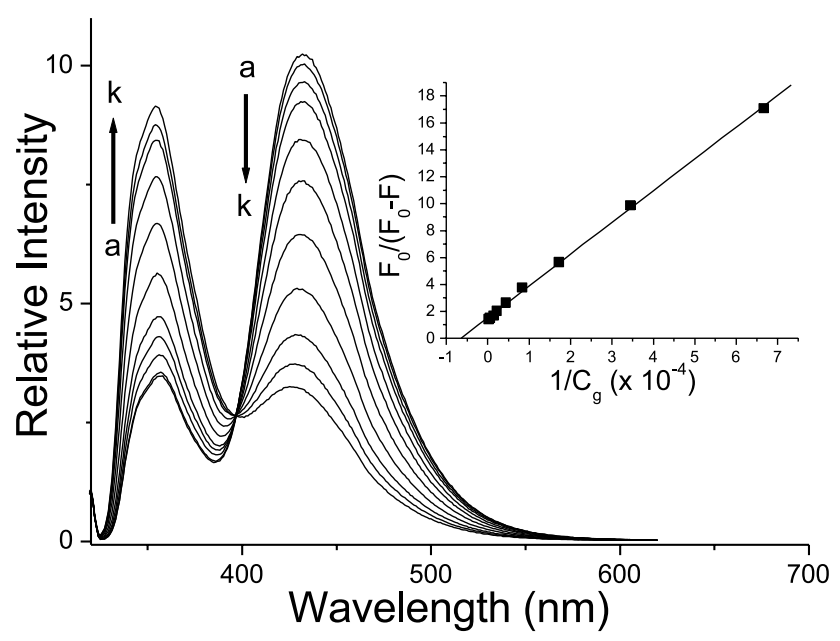

Figure 5. Fluorescence spectra of $2 \mathbf{a}\left(3.2 \times 10^{-5} \mathrm{M}\right)$ in $\mathrm{CH}_{3} \mathrm{CN}$ by adding $\mathrm{NaClO}_{4}$ concentrations $\left(C_{\mathrm{g}}\right.$ ) of (a) 0 , (b) 1 , (c) 5, (d) 10, (e) 20, (f) 40, (g) 80 , (h) 160 , (i) 230 , (j) 650 , (k) 1300 equiv $\left(1\right.$ equiv $\left.=2.9 \times 10^{-6} \mathrm{M}\right)$. Insert: the plot of $F_{0} / F-F_{0}$ against $1 / C_{\mathrm{g}}, \lambda_{\mathrm{ex}}: 320 \mathrm{~nm}$. with respect to the $S_{0}-S_{1}\left(\pi \pi^{*}\right)$ absorption of $\mathbf{2} \mathbf{a}$, can be unambiguously ascribed to the emission associated with the normal form of 2a in that the intramolecular hydrogen bond is ruptured due to the strong solute-solvent polar-polar interaction in $\mathrm{CH}_{3} \mathrm{CN}$. ESIPT is thus prohibited during the lifespan of the excited conformer $\mathbf{C}$. It should be noted that the existence of conformer $\mathbf{C}$ is negligible in $\mathbf{1 a}$ due to its dual HB sites, that is, conformers $\mathbf{A}$ and $\mathbf{B}$, providing an intact intramolecular $\mathrm{HB}$ environment free from solvent perturbation.

Titration of 2a by $\mathrm{NaClO}_{4}$ revealed a similar hypsochromic absorption shift with that of $\mathbf{1 a}$, and an association constant of $(5.5 \pm 0.5) \times 10^{3} \mathrm{M}^{-1}$ was deduced in $\mathrm{CH}_{3} \mathrm{CN}$ (not shown here). During titration the $432 \mathrm{~nm}$ emission band decreased, accompanied by the increase of a $355 \mathrm{~nm}$ normal emission $\left(\tau_{\mathrm{f}}=4.6 \mathrm{~ns}\right)$ with an isoemissive point at $397 \mathrm{~nm}$. The results lead us to conclude the rupture of the $\mathrm{O}-\mathrm{H} \cdots \mathrm{N}$ hydrogen bond on the formation of the $\mathbf{2} \mathbf{a} / \mathrm{Na}^{+}$complex so that ESIPT is prohibited, giving rise to a normal Stokes shifted emission. This is quite different from 1a in that the conformation of $1 \mathrm{a}$ switches from the $\mathrm{OH} \cdots \mathrm{N}$ to the $\mathrm{OH} \cdots$ $\mathrm{O}=\mathrm{C}$ site upon $\mathbf{1 a} / \mathrm{Na}^{+}$complexation, resulting in a weak keto-tautomer emission (vide supra). In comparison to $\mathbf{2 a}$, the $\sim$ 4-folds larger $\mathrm{K}_{\mathrm{a}}$ value in $1 \mathrm{a}$ can be rationalized by the more stable $1 \mathrm{a} / \mathrm{Na}^{+}$complex due to the intramolecular $\mathrm{OH} \cdots \mathrm{O}=\mathrm{C}$ hydrogen bond formation.

Attempts have also been made to titrate DMHN with $\mathrm{Na}^{+}$. The results revealed negligible spectral differences, verifying the importance of capping $\mathrm{Na}^{+}$with 1-aza-15-crown-5 ether in 1a and 2a. Furthermore, within the same range of concentrations, absorption and emission titration remained unchanged on adding $\mathrm{K}^{+}$to both $1 \mathrm{a}$ and $\mathbf{2 a}$, and the results can simply be rationalized by the mismatched sizes between $\mathrm{K}^{+}$and 1-aza-15-crown-5 ether.

The absorption and emission spectra of $\mathbf{1 a}$ as a function of the divalent metal ions, for example, $\mathrm{Ca}^{2+}$, in $\mathrm{CH}_{3} \mathrm{CN}$ are shown in Figure 6. Upon an increase in $\left[\mathrm{Ca}^{2+}\right]$, a decrease in the $393 \mathrm{~nm}$ absorption band was observed, accompanied

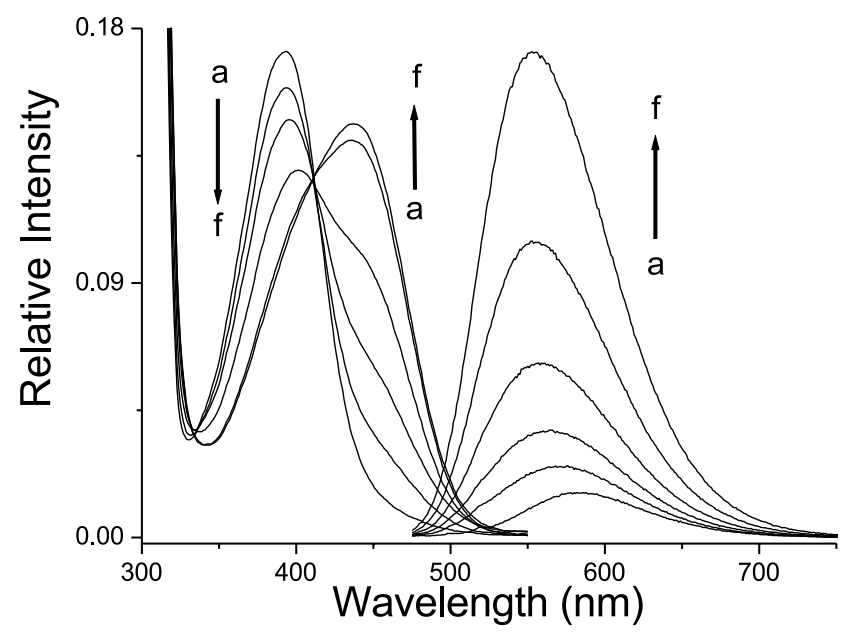

Figure 6. Absorption and emission spectra of $1 \mathrm{a}\left(3.2 \times 10^{-5} \mathrm{M}\right)$ in $\mathrm{CH}_{3} \mathrm{CN}$ by adding $\mathrm{Ca}^{2+}$ concentrations $\left(C_{\mathrm{g}}\right.$ ): (a) 0 , (b) 1 , (c) 2 , (d) 4 , (e) 6 , (f) 8 , (g) 18 , (h) 23 , (i) 28 , (j) 33 equiv ( 1 equiv $\left.=2.9 \times 10^{-6} \mathrm{M}\right), \lambda_{\mathrm{ex}}: 450 \mathrm{~nm}$. 


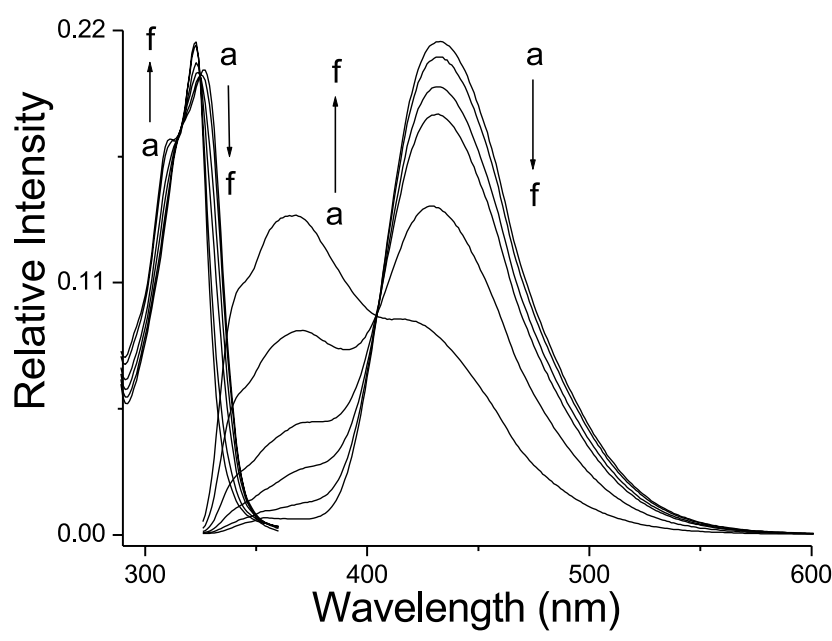

Figure 7. Absorption and emission spectra of $2 \mathbf{a}\left(3.2 \times 10^{-5} \mathrm{M}\right)$ in $\mathrm{CH}_{3} \mathrm{CN}$ by adding $\mathrm{Ca}^{2+}$ concentrations $\left(C_{\mathrm{g}}\right)$ : (a) 0 , (b) 2 , (c) 4, (d) 6, (e) 10 , (f) 15 equiv $\left(1\right.$ equiv $\left.=2.9 \times 10^{-6} \mathrm{M}\right) . \lambda_{\text {ex }}: 320 \mathrm{~nm}$.

by the gradual increase of a new band maximized at $438 \mathrm{~nm}$ and the appearance of an isosbestic point at $412 \mathrm{~nm}$. The straight-line plot of $A_{0} /\left(A-A_{0}\right)$ versus $1 /\left[\mathrm{Ca}^{2+}\right]$ confirms a $1: 1 \mathrm{1a} / \mathrm{Ca}^{2+}$ complexation, and an association constant of $(3.8 \pm 0.4) \times 10^{4} \mathrm{M}^{-1}$ was deduced. Upon $450 \mathrm{~nm}$ excitation, the increase of fluorescence intensity as a function of $\left[\mathrm{Ca}^{2+}\right]$ was observed, and the emission peak wavelengths shifted from 580 to $560 \mathrm{~nm}$ (Fig. 6). During titration, the relaxation dynamics of the entire band could be well fitted by biexponential decay kinetics, and lifetimes were resolved to be 4.7 and $7.1 \mathrm{~ns}$, indicating the existence of two distinct species. Due to its spectral similarity with that of the $\mathrm{KOH}$ basified 1a oxide (in $\mathrm{MeOH}$ ), the $438 \mathrm{~nm}$ absorption band can be assigned to a $1 \mathrm{a} / \mathrm{Ca}^{2+}$ complex absorption, in which the hydroxyl proton is detached to form oxide, along with the nitrogen atom binding to $\mathrm{Ca}^{2+}$, giving rise to a $560 \mathrm{~nm}$ $\left(\tau_{\mathrm{f}} \sim 7.1 \mathrm{~ns}\right)$ anion emission. In a comparative study, although similar spectral change was observed upon titration of DMHN with $\mathrm{Ca}^{2+}$, the association constant of $(8.0 \pm 0.3) \times 10^{3} \mathrm{M}^{-1}$ is smaller than that of the $1 \mathrm{a} / \mathrm{Ca}^{2+}$ complex by $\sim$ five folds. We thus conclude that in addition to oxide $\left(\mathrm{O}^{-}\right)$and nitrogen atoms, the remaining ether

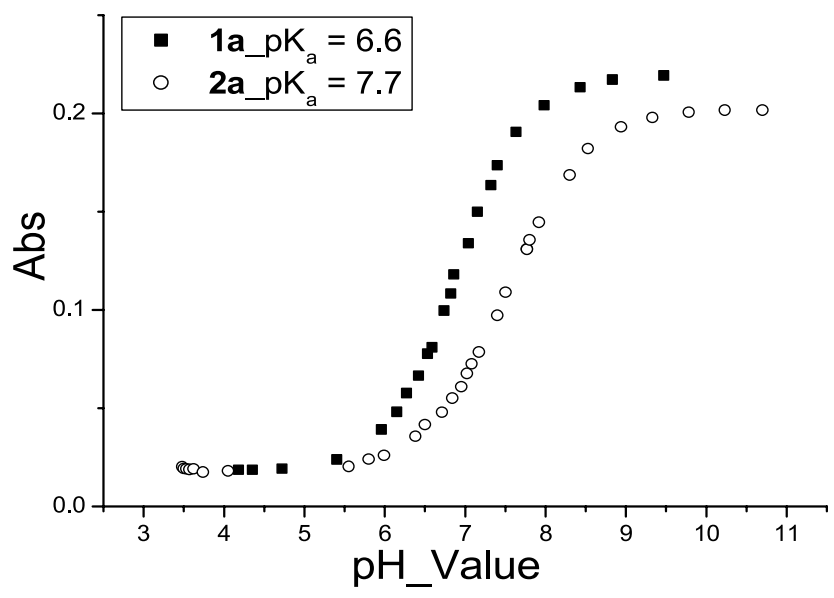

Figure 8. The ground-state $\mathrm{pH}(\mathrm{NaOH})$ titration experiment for $\mathbf{1 a}(\square)$ and 2a ( ) in water. Data were obtained from the $\mathrm{pH}$ dependent absorbance at $450 \mathrm{~nm}$ and $350 \mathrm{~nm}$ for $\mathbf{1 a}$ and $\mathbf{2 a}$, respectively. oxygens in azacrown are also incorporated in the $1 \mathrm{a} / \mathrm{Ca}^{2+}$ complexation. A similar coordination structure has been reported in a $\left(\left[\mathrm{Ca}(1\right.\right.$-aza-15-crown-5 ether $\left.)\left(\mathrm{CH}_{3}-\mathrm{OH}\right)_{2}\right]$ $\left.\mathrm{BPh}_{4}\right)$ single crystal. ${ }^{14}$

In contrast to the oxy-anion characteristic for the $1 \mathrm{a} / \mathrm{Ca}^{2+}$ complex, drastically different $\mathrm{Ca}\left(\mathrm{ClO}_{4}\right)_{2}$ titration spectra for $2 \mathbf{a}$ were observed, in which increasing $\mathrm{Ca}^{2+}$ resulted in a hypsochromic spectral shift with an appearance of an isosbestic point at $324 \mathrm{~nm}$ (Fig. 7). The lack of oxide absorption indicates that the hydroxyl group remains intact in $2 \mathbf{a}$ during the $\mathrm{Ca}^{2+}$ titration. This viewpoint is further supported by a decrease of the $435 \mathrm{~nm}$ zwitterion emission during the titration, accompanied by an increase of the $360 \mathrm{~nm}$ normal emission with an isoemissive point appearing at $405 \mathrm{~nm}$. The difference in capping $\mathrm{Ca}^{2+}$ can be qualitatively rationalized by the stronger acidity of the hydroxyl group in $\mathbf{1 a}$ due to the aldehyde $(\mathrm{CHO})$ electron withdrawing property $(\mathrm{p} K \mathrm{a} \sim 6.6$ in $\mathbf{1 a}$ versus $\sim 7.7$ in $\mathbf{2 a}$ according to the $\mathrm{pH}$ titration shown in Fig. 8). The dissimilar binding property is also manifested by the association strength, in which $K_{\mathrm{a}}$ of $(1.2 \pm 0.3) \times 10^{4} \mathrm{M}^{-1}$ for $\mathbf{2 a}$ is smaller than that of $\mathbf{1 a}$ by more than three folds.

\section{Conclusion}

In conclusion, we have reported the design and synthesis of a new type of metal-cation probes $\mathbf{1 a}$ and $\mathbf{2 a}$, in which 1-aza-15-crown-5 ether in combination with a hydroxyl group acts as a receptor, while a mechanism of switch or prohibition of ESIPT upon complexation is exploited as the signal transducer. 1a is superior to 2 a owing to its larger $K_{\mathrm{a}}$ values and metal-ion-selective spectral change. It is thus conceivable to design multiple HB systems capable of sensing bio-analytes based on the ESIPT mechanism. Further work focusing on this issue is currently in progress.

\section{Acknowledgements}

We thank the National Science Council for financial support.

\section{References and notes}

1. (a) Kosower, E. M.; Huppert, D. Ann. Rev. Phys. Chem. 1986, 37, 127-156. (b) Special Issue Spectroscopy and Dynamics of Elementary Proton Transfer in Polyatomic Systems; Firth, D., Barbara, P. F., Trommsdorff, H. P., Eds.; Chem. Phys. 1989, 130, 349-360. (c) Formosinho, S. F.; Arnaut, L. G. J. Photochem. Photobiol. A Chem. 1993, 75, 21-48. (d) Scheiner, S. J. Phys. Chem. A 2000, 104, 5898-5909. (e) Waluk, J. Conformational aspects of intra- and intermolecular excited state proton transfer. In Conformational Analysis of Molecules in Excited States; Waluk, J., Ed.; Wiley, 2000. (f) Chou, P. T. J. Chin. Chem. Soc. 2001, 48, 651-682. (g) Elsaesser, T. Ultrafast excited state hydrogen transfer in the condensed phase. In Ultrafast Hydrogen Bonding Dynamics and Proton 
Transfer Processes in the Condensed Phase; Elsaesser, T., Bakker, H. J., Eds.; Kluwer: Dordecht, 2002.

2. Chou, P. T.; McMorrow, D.; Aartsma, T. J.; Kasha, M. J. Phys. Chem. 1984, 88, 4596-4599.

3. Acuna, A. V.; Amat, F.; Catalán, J.; Costella, A.; Figuera, J. M.; Munoz, J. M. Chem. Phys. Lett. 1986, 132, 567-569.

4. Parsapour, F.; Kelley, D. F. J. Phys. Chem. 1996, 100, 2791-2798.

5. Sytnik, A.; Kasha, M. Proc. Natl. Acad. Sci. 1994, 91, 8627-8630.

6. Catalán, J.; del Valle, J. C.; Claramunt, R. M.; Sanz, D.; Dotor, J. J. Lumin. 1996, 68, 165-170.

7. Renschler, C. L.; Harrah, L. A. Nucl. Instrum. Methods Phys. Rev., A235, Sept., U.S. Patent 1985, 635-639.

8. Wu, K. C.; Cheng, Y. M.; Lin, Y. S.; Yeh, Y. S.; Pu, S. C.; Hu, Y. H.; Yu, J. K.; Chou, P. T. Chem. Phys. Lett. 2004, 384, 203-209.

9. (a) For fluorescent $\mathrm{Ca}^{2+}$ metal ion chemosensors, see: Mlyamaki, A.; Llopis, J.; Holm, R.; McCarffery, J. A.;
Ikurn, M.; Tsien, R. Y. Nature 1997, 388, 882-887. (b) Arunkumar, E.; Chithra, P.; Ajayaghosh, A. J. Am. Chem. Soc. 2004, 126, 6590-6598. (c) Yamniuk, A. P.; Nguyen, L. T.; Hoang, T. T.; Vogel, H. J. Biochemistry 2004, 43, 2558-2568.

10. Roshal, A. D.; Grigorovich, A. V.; Doroshenko, A. O.; Pivovarenko, V. G. J. Phys. Chem. A 1998, 102, 5907-5914.

11. Lakowicz, J. R. Principles of Fluorescence Spectroscopy; Plenum: New York, 1999; pp 185-192.

12. Chou, P. T.; Wu, G. R.; Wei, C. Y.; Cheng, C. C.; Chang, C. P.; Hung, F. T. J. Phys. Chem. B 2000, 104, 7818-7829. $A_{0}, F_{0}, A$ and $F$ denote respectively the absorbance and fluorescent intensity of free 1a, and solution after adding metal ions at a selective wavelength.

13. Tolbert, L. M.; Nesselroth, S. M. J. Phys. Chem. 1991, 103, 10331-10336.

14. Itoh, S.; Kumei, H.; Nagatomo, S.; Kitagawa, T.; Fukuzumi, S. J. Am. Chem. Soc. 2001, 123, 2165-2175. 